\title{
Impact Investing: World Trends And The Problems Of Its Implementation In Ukraine
}

\author{
Iryna Vasylchuk \\ Department of Finance, Banking and \\ Insurance \\ Kryvyi Rih Economic Institute of Kyiv \\ National Economic University named \\ after Vadym Hetman \\ Kryvyi Rih, Ukraine \\ vasylchuk_ip@kneu.dp.ua
}

\author{
Kateryna Slyusarenko* \\ Department of International Economics \\ Kryvyi Rih Economic Institute of Kyiv \\ National Economic University named \\ after Vadym Hetman \\ Kryvyi Rih, Ukraine \\ slusarenko_kv@kneu.dp.ua
}

\author{
Maryna Sadovenko \\ Department of Finance, Banking and \\ Insurance \\ Kryvyi Rih Economic Institute of Kyiv \\ National Economic University named \\ after Vadym Hetman \\ Kryvyi Rih, Ukraine \\ sadovenko_mm@kneu.dp.ua
}

\begin{abstract}
Development of socially responsible investing is a necessary condition of reforming the modern economy considering economic instability in Ukraine. The rapidly growing part of assets around the world is forcing to make a choice of investments focused not only on returns, but also on sustainability and compliance with social values. Adapting the world models of impact investments to the realities of the domestic economy requires detailed consideration of their peculiarities.

Therefore, the authors of this article researched world and domestic trends of impact investing and defined the problems and directions of activation of this type of investment in Ukraine. They studied the concept of "impact investing" as well as determined its criteria and principles. The analysis of foreign experience of impact investing has showed wide possibilities of using this instrument in real investment. Therefore, the necessity of the system transformation of real investment and to promote the development of social impact investments in Ukraine is substantiated.
\end{abstract}

Keywords - socially responsible investment; impact investing; strategies of socially responsible investing; social influence; sustainable development.

\section{INTRODUCTION}

In the context of economic instability, social and environmental crisis in Ukraine, a necessary condition for reforming the modern economy is the development of socially responsible investing, as the main factor in achieving sustainable development of Ukraine.

It is worth noting that sustainable development is a new worldview, political and practical development model for all countries of the world that have begun to move from a purely economic development model to an optimal balance between the three components of the development - economic, social and environmental ones. The implementation of this model requires the establishment of the system of public management of sustainable development, the necessary condition of which and its important component is appropriate governance.

The introduction of the projects connected with sustainable development requires the involvement of significant investments. In the activities of the present-day, investment practices are changing. The rapidly growing share of assets all over the world is forcing a choice of investments focused not only on profitability, but also on sustainability and compliance to values.
The development of impact investing was researched by foreign and domestic scientists such as: Stanley M., $\mathrm{H}$. Edwards, N. V. Ivanova, L. M. Salamon, V. Smal, V. Kokot, A. Nichols, R. Paton, D. Emersonta and others [1]-[14].

However, in Ukraine, the practice of socially responsible investing, including impact investing, has not been spread among investors. Therefore, the study of world trends of impact investments requires systematization and adaptation for the development of high-level social responsibility and dominant environmental safety of doing business in Ukraine.

The purpose of the article is to study the world trends of impact investing in the developed countries, analyze socially responsible investment in Ukraine and determine the directions of intensification of social initiatives for the development of entrepreneurship in the sphere of investments.

\section{Presentation OF THE MAIN RESEARCH MATERIAL}

The overcoming of the economic crisis and forming objective prerequisites for the sustainable development of Ukraine's economy is impossible without real investing, renewal of fixed capital, restructuring of the entire financial and investment sphere and the creation of the favorable investment climate as an important competitive advantage of further economic development of the system.

Ukraine, like most countries of the world, supported the concept of sustainable development, which leads to the fulfillment of socially oriented requirements in various fields. With regard to sustainable development, needs are met without prejudice to future generations.

The sustainable development of the state includes costeffective, socially equitable and environmentally sound development. Therefore, the new world paradigm of the development of Ukraine and other countries of the world should meet the needs of the present generation without prejudice to the possibility for future generations. Such model of the development of the organization is aimed at achieving high economic efficiency, high-level social responsibility and dominant environmental security. This gives priority to the development of socially responsible investing to overcome social problems in Ukraine, connected not only with the global crisis, but also with excessively long-term reforms.

Socially responsible investing is manifested in the concept of socially responsible business. The practice of 
combining business investments with a dualistic goal, namely, making profit and achieving positive social/environmental changes in the society, is becoming increasingly popular and widespread. Such model of investing in practice forms a new type of compromise commercial-social or commercial-ecological entrepreneurship with impact investing. At the same time, an alternative method of investments of such model is used for the implementation of state social or environmental programs of different levels with a focus on small and medium-sized businesses and subsequent calculation of the quantitative social/environmental effect [5], [15].

First time the term «impact investing» was used by the Rockefeller Foundation in 2007, and it launched an initiative to attract the capital of private investors to finance social enterprises [5]. Many modern economists and economic organizations have interpreted the concept of impact investing (Table 1).

Generalizing, you can say that for today impact investing according to its contents is a certain type of socially responsible investing, in particular investing in projects that aim to achieve a positive social effect.

In addition, such investments have a number of fundamental differences. Thus, in fact, impact investments, while not denying generally accepted views on the solution of social and environmental problems through the State or charity, simultaneously provide that financial investments can be carried out not only for the purpose of obtaining a financial result, but also for the purpose of receiving a social effect.

Socially responsible investing focuses on three factors of sustainable development: environmental, social and corporate governance, and consists in taking into account during decision-making the potential of social and environmental risks related to financing, and also establishing systems for managing these risks.

The algorithm of action of the organizations that use the principles of socially responsible financing in their activities is typical. In the first stage, companies applying for funding are checked for compliance with the above principles. If there are violations of investment activities, these companies are prohibited. Companies that adhere to principles and receive investment funds from financial institutions officially support these initiatives aimed at maximizing their financial efficiency while secondary solving social problems, achieving social results. Therefore, socially responsible investing is called passive and narrowly directed [5].

Drawing on the above, impact investing provides for decision of social and environmental problems owing to the use of new investment instruments in investment territories. The main participants in impact investment are the recipient of the investment, the intermediary determining the criteria of projects applying for financing, and the investor. At the same time, the investor deliberately takes into account the goals and values of other participants when achieving his/her goals. Thus, in the case of impact investments, the high financial efficiency of the project, the stable financial position of the borrowing company and the observance of ethical principles are necessary but insufficient to make a decision. The possibility of achieving a pre-assessed social and/or environmental impact is important.

The Global Impact Investing Network (GIIN) defined four criteria by which investments can be classified as impact investments [8] (Figure 1):

1. Setting targets. In the business plan it is necessary to specify social goals, thus to determine what social effect will be achieved with the results.

2. Return of investment. An indicator that reflects the return on investment (ROI). This criterion will allow the development of markets for financing social projects. It is worth remembering that impact investments focus on a long payback period.

3. Spectrum of return. This indicator can be different: it can be equal to $1 \%, 5 \%, 20 \%$. There must be a relationship between the social outcome, effect and economic benefit. At the same time, revenues can be generated both at market rates and at rates below market ones.

4. Measurement and assessment of social impact. It is necessary for the report to define firmly that the social goal has been achieved. It is also important to show contributions to real-world issues [8].

The United Nations Development Program (UNDP) defines three main principles of impact investing [9]:

- profitability (the rate of return can be both higher and lower than the market average);

TABLE I. Comparative Description Of The Authors' Interpretations Of The Essence Of Impact Investing

\begin{tabular}{|c|c|}
\hline Author & Disclosure of impact investing \\
\hline $\begin{array}{l}\text { Bugg-Levine A., } \\
\text { Emerson J. }\end{array}$ & $\begin{array}{l}\text { Impact investing focuses on obtaining a combined value as the combination of social, environmental and economic effectiveness } \\
\text { [15]. }\end{array}$ \\
\hline $\begin{array}{l}\text { Evolution and } \\
\text { Philanthropy } \\
\text { company }\end{array}$ & $\begin{array}{l}\text { These are the funds directed to the social sphere in order to obtain social results and effects, which are expressed in improving the } \\
\text { quality of life and increasing the autonomy of the recipients of the benefits, developing their knowledge and skills, and are of a } \\
\text { long-term nature [7]. }\end{array}$ \\
\hline $\begin{array}{l}\text { Global Impact } \\
\text { Investing Network }\end{array}$ & The term "impact investing" is understood as an investment for social and/or environmental impact, together with profit [2]. \\
\hline $\begin{array}{l}\text { Nicholls A., Paton } \\
\text { R., Emerson J. }\end{array}$ & $\begin{array}{l}\text { Impact investing is investing that aims to generate special beneficial social or environmental effects in addition to financial gain. } \\
\text { Impact investing is a subgroup of socially responsible investing (SRI), but while the definition of socially responsible investing } \\
\text { involves avoiding harm, impact investing actively seeks to make a positive impact by investing, for example, in non-profit } \\
\text { organizations that benefit society or enterprises with clean technologies [1]. }\end{array}$ \\
\hline Bazilyuk B. G. & $\begin{array}{l}\text { Social investing that means attracting financing for social organizations - involves both social impact (broader social, } \\
\text { environmental and social goals) and financial results (returns) [14]. }\end{array}$ \\
\hline Blagov Yu. E. & $\begin{array}{l}\text { Impact investments are investments "in companies, organizations and funds for the purpose of creating a measured, socially or } \\
\text { environmentally useful effect, as well as for obtaining financial return." The term "impact investing" is broader, since in the } \\
\text { concept of impact investing there is "the desire for profit together with the benefit of society, the solution of environmental } \\
\text { problems and social justice" [16]. }\end{array}$ \\
\hline Kraplich R. & $\begin{array}{l}\text { These are the financial investments that enable the recipient to carry out a project or program for a long time. The result of impact } \\
\text { investing is reflected in the development of the area, the protection of interests and the provision of the main needs of the target } \\
\text { groups of the population, the constant trusteeship of public institutions and the constant improvement of well-being [17]. }\end{array}$ \\
\hline $\begin{array}{l}\text { Seryakov A.V., } \\
\text { Shikhverdiyev A.P. }\end{array}$ & mpact investments are investments that benefit both the public and the company [18]. \\
\hline
\end{tabular}


- a positive impact on society and the environment;

- responsible assessment of project results - investors should monitor whether they achieve their social or environmental objectives (Figure 1).

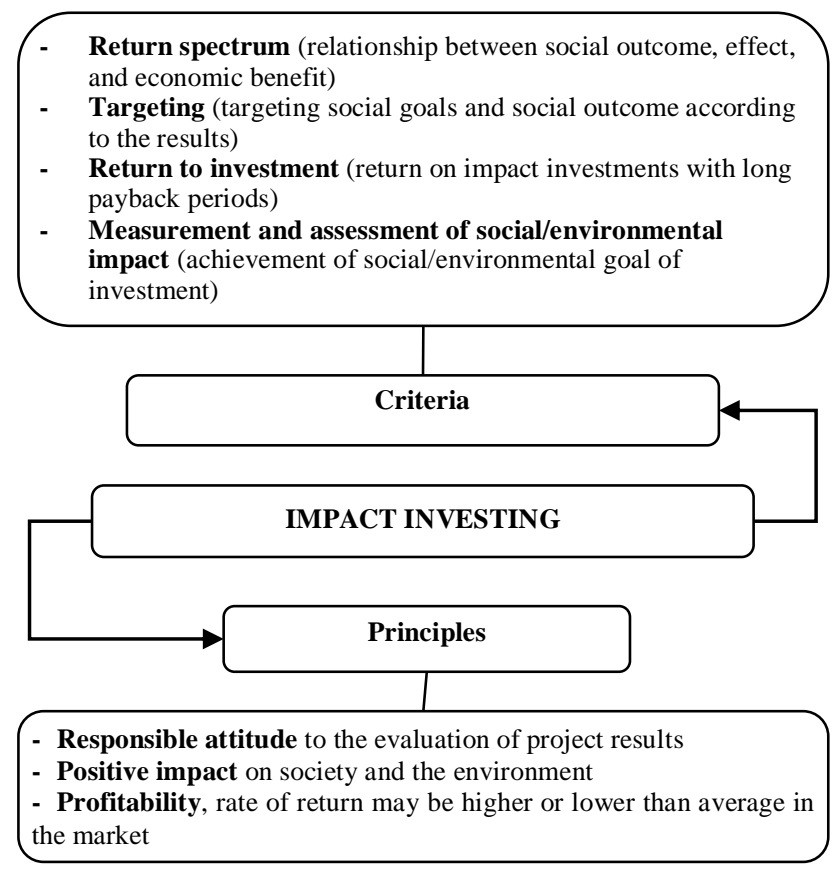

Fig. 1. Criteria and principles of impact investing a

$$
\text { a made by the authors on the basis of [8], [9] }
$$

Impact investors have a possibility to place their capital in enterprises, non-profit organizations or foundations. Popular investment instruments can be the purchase of a share in capital or a loan. Impact investments come into social business in most cases at an early stage, such as a startup or a venture.

Impact investing attracts a wide range of investors, both private and institutional ones. The investors can be the following: fund managers; hedge funds; diversified financial institutions and banks; investment funds; pension funds and insurance companies; individual investors; non-profit organizations. The Case Foundation identifies the next types of impact investments [19]:

1. Impact motivated investments. Some investors claim that many of their investments have a social impact. They certainly want the funds to be invested in job creation, service delivery to yield only positive results. Such investors could be described as impact-motivated. They focus on financial return, seek positive influence and follow program values [19]. For instance, social enterprise Sanergy produces high-quality toilets designed for urban slums in Kenya. The company engages local residents and also organizes a centralized collection of waste, which is then converted into organic fertilizers for farmers. With this affordable and hygienic technology, the company improves sanitation conditions, contributes to the reduction of disease and poverty in low-income society, which is deprived of sanitation and electricity. In 2013, Sanergy investors were Acumen Foundation, Spring Hill Equity Partners [20].

2. Impact-ideological investments. They demonstrate the intention of social impact. They focus on transparency and regular reporting. Companies set their own targets and performance indicators, which can be both three, and thirty.
For example, to measure its effectiveness, the world leader social company D.light tracks results in four areas: financial freedom, improving productivity, the health of residents and improving the environment [19].

3. Impact-tested investments. B Lab, a non-profit organization, has created special certificates (B Laboratory certification or B Corporate certification) for companies that meet the criteria of social and environmental efficiency. Companies with such certificates can be classified as socially responsible investors [19].

For example, the company D.light has B Corporation certificate. It actively attracts investments. The shareholders of the company were Acumen, Omidyara Network and Gray Ghost Ventures. Some investors have introduced their representatives to the board of directors of D.light. The aim of the company is to create free access to a reliable light source for customers in developing countries. The company operates and sells its products in 40 countries [20].

Responsible investing strategies and the initiatives in the field of socially responsible investment were given attention in the research made by a number of international organizations. Table 2 shows the comparison of the European Association for Fund and Asset Management (EFAMA), the United Nations Principles for Responsible Investment (PRI) and the Global Alliance for Sustainable Development Investment (GSIA) of approaches to the classification of investment strategies.

TABLE II. List Of Classifications Of Socially Responsible Investment Strategies ${ }^{\mathrm{A}}$

\begin{tabular}{|c|c|c|}
\hline \multicolumn{3}{|c|}{ Classification by the version } \\
\hline $\begin{array}{c}\text { Of Global Alliance for } \\
\text { Sustainable } \\
\text { Development } \\
\text { Investment (GSIA) }\end{array}$ & $\begin{array}{l}\text { Of UN Principles } \\
\text { for Responsible } \\
\text { Investment (PRI) }\end{array}$ & $\begin{array}{c}\text { Of European } \\
\text { Association for Fund } \\
\text { and Asset Management } \\
\text { (EFAMA) }\end{array}$ \\
\hline $\begin{array}{l}\text { ESG- negative } \\
\text { screening }\end{array}$ & $\begin{array}{c}\text { ESG- negative } \\
\text { screening/exclusion }\end{array}$ & $\begin{array}{c}\text { Negative screening or } \\
\text { exclusion }\end{array}$ \\
\hline $\begin{array}{l}\text { Norms-based } \\
\text { screening }\end{array}$ & $\begin{array}{l}\text { Norms-based } \\
\text { screening }\end{array}$ & Norms-based approach \\
\hline $\begin{array}{c}\text { ESG- Positive } \\
\text { Approach and best-in- } \\
\text { class }\end{array}$ & $\begin{array}{c}\text { ESG- Positive } \\
\text { Approach and best- } \\
\text { in-class }\end{array}$ & Best-in-class \\
\hline $\begin{array}{c}\text { Sustainability themed } \\
\text { investing }\end{array}$ & $\begin{array}{l}\text { ESG- themed } \\
\text { investing }\end{array}$ & Themed investing \\
\hline $\begin{array}{c}\text { Corporate interaction } \\
\text { and shareholder voting }\end{array}$ & Interaction & Interaction (voting) \\
\hline ESG-integration & $\begin{array}{c}\text { Integration of ESG } \\
\text { criteria }\end{array}$ & - \\
\hline $\begin{array}{l}\text { Impact investments } \\
\text { (impact investing) }\end{array}$ & - & - \\
\hline
\end{tabular}

GSIA's seven core socially responsible investment strategies differ in sustainability and responsibility criteria (or ESG criteria in different types and forms). Among such investment strategies are: ESG-negative screening, regulatory screening; ESG - positive approach and best-inclass; sustainability themed investing; corporate interaction and shareholder voting; ESG integration; impact investments. The comparative analysis of approaches made by the international organizations on the strategy of responsible investment at the present stage establishes standard positions on the first five strategies with adjustment in names. Despite the relevance and high prevalence of impact investments, PRI and EFAMA do not highlight this type of investment [22].

ESG-negative screening is considered the main strategy of socially responsible investment, based on the fact that 
responsible investors exclude from their securities portfolios companies that have unfair business reputation and do not comply with legislative requirements, carry out activities related to production and promotion of harmful products, invest in parallel hazardous business, are engaged in morally questionable activities [22]. Such strategy involves ignoring investments by companies whose business causes significant damage to the environment, violates labor laws etc.

Norms-based screening consists of exclusion from the portfolio of companies, that do not systematically observe the principles of corporate social responsibility set out in the main international instruments (UN Global Compact, Basic Conventions of the International Labour Organization, OECD Guidelines for TNCs). Investment is concentrated mainly on facilities that comply with international norms and standards in the social and environmental spheres, as well as in the sphere of corporate governance [22].

The strategy ESG-Positive approach and best-in-class include the selection of companies that have little impact on the environment or have active social policies, as well as the best results in their sector or in a certain direction. For this purpose, investors use their own screening databases and specialized databases of professional research organizations, specialized non-profit organizations in combination with media resources [22].

Sustainability themed investing involves investing in assets or thematic investment funds that address sustainable development issues (e.g., preventing global climate change and lack of drinking water, eco-technology development, health, renewable energy production and use, efficient use of natural resources).

Corporate interaction and shareholder voting provides for investors to submit issues of corporate governance and corporate social responsibility to the general meeting of shareholders; to initiate an extraordinary general meeting; to attend the annual general meetings; to participate in voting on issues related to social responsibility, corporate governance, social and environmental policy of the company, etc. [22]. ESG integration involves a thorough analysis of ESG criteria together with financial indicators and is aimed at identifying the potential. impact (negative or positive) of social, environmental and management factors on the company's development.

Impact investments (impact investing) involve investing in companies that generate exclusively social or environmental positive effects with the possibility of its calculating or otherwise confirming it.

It is worth noting that the above-mentioned strategies are not mutually exclusive or universal. In practice, they complement each other, allowing an investor not only to select objects and issuers, but also to interact with them from the position of the shareholder in issues of corporate social responsibility [22].

Europe is now actively investing through ESG-Negative Screening and Regulatory Screening and Corporate Interaction Strategy Toolkit (Figure 2). At the same time, the new trend of impact investing has become widespread worldwide, especially in the context of investment in enterprises whose activities involve low-carbon production and the development of social infrastructures.

Such investing obliges entrepreneurs to calculate as a result not only the return on investment, but also the social/environmental impact achieved. The main philosophy of impact investing is to have a positive social/environmental impact on sustainable development [22]. In 2015, the largest growth in these financial flows (by $120 \%$ ) occurred, while against the background of financial crisis events priority was given to investing in more profitable projects.

Producers and investors are increasingly gaining support for their property rights. As a result, impact investing in Europe is characterized by sustainable development at the level of 5\% (108 billion Euro) in 2017.

Despite moderate growth, positive dynamics indicate that investors are aware of their potential and want to earn on the difference by choosing specific categories of investments [22]. More and more investors are turning to this strategy, which is defined as the ideal one among socially directed strategies and promises a bigger effect than just making a profit.

Impact investing has been for a long time a niche market for well-capitalized companies.

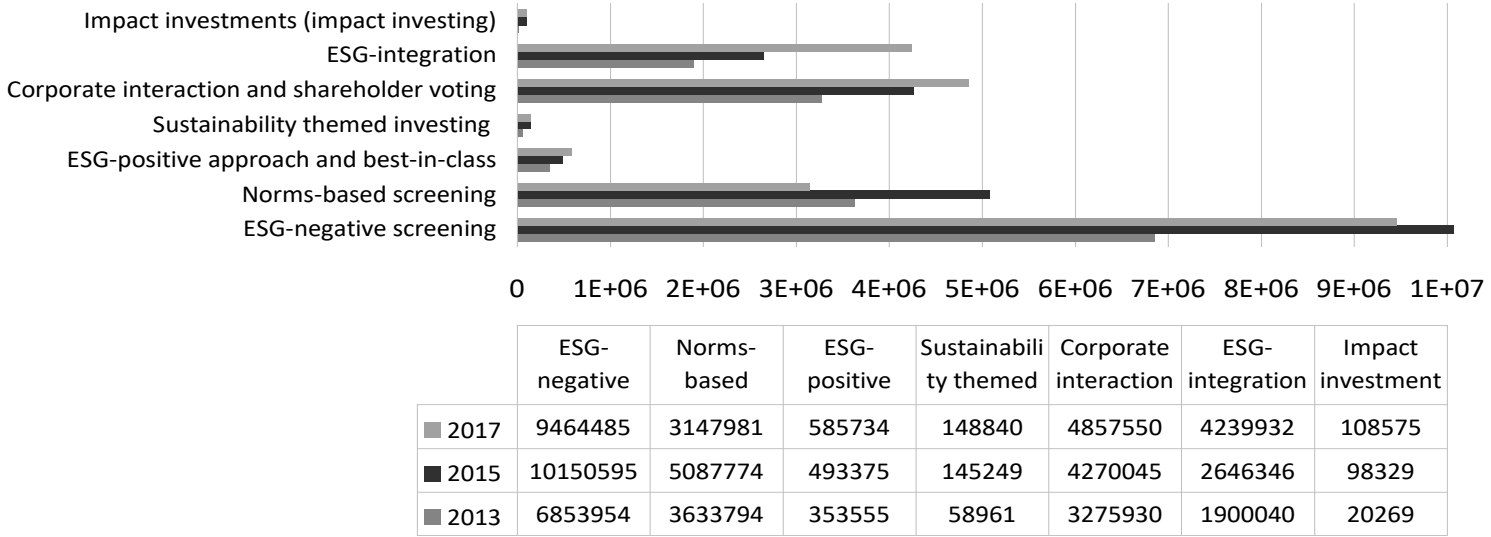

Fig. 2. Investments in terms of strategies in Europe, million Euro ${ }^{\mathrm{a}}$ 
Today, they are a growing component of portfolios for different levels of investors, and even constituent organizations such as the World Economic Forum, the G8 and the Aspen Institute are exploring the ways to attract them. Global Impact Investing Network estimates global investment in such projects at the level of 228 billion US dollars as of 2017. On a global scale, it is not so much, but this direction is developing very quickly [8]. As in 2014 the total estimate of impact investment projects barely exceeded 10 billion US dollars, that is, as we can see, an increase of 22 times. Among impact investors there are many well-known names: Bill \& Melinda Gates Foundation, JP Morgan, Black Rock, Goldman Sachs, Bank of America, LokCapital, LeapFrog Investments, LGT Impact Ventures and so on. Companies and people who are thinking about the transformational impact of their business are getting bigger [10]. For example, LokCapital is a fund that promotes inclusive growth in India through long-term equity investment. The Drishti-Eye Center provides comprehensive eye care for the part of the population that previously did not have access to quality eye care due to the amalgamation of hospitals, vision centers and mobile eye clinics [8].

LeapFrog Investments (LeapFrog) invests in the companies, which provide medical and financial services for new consumers in Africa and Asia. From 1 billion US dollars of assets under management, it brings capital and additional services that specialize in the experience of its partner companies. LeapFrog aims to make a profit for purpose by providing private capital returns and measurable social impact [8]. LGT Impact Ventures invests in target companies that have scalable business models and provide people with disabilities with access to basic services, products and livelihood opportunities in growth markets. The doctor provides high quality, low-cost medical and diagnostic services to low- and middle-income population in Brazil. The investments of LGT ImpactVentures into Dr. Consulta were used to expand the clinical network up to 10 clinics [8].

The support of projects in accordance with the mission of the funds is a clear example of international impact investment. For example, the Dutch development fund FMO invested in Mongolian companies Clean Energy to build the first wind farm near the Mount Salhi. This investment has helped increase the use of renewable energy sources and gain access to Asian markets [8].

The American Packard Foundation invests in sustainable forest management. The foundation invested $\$ 1,000,000$ in forestry management company Ecotrust Forests. The funds will be used to manage naturally and restore nearly 13,000 acres of forested land. The motive of the fund for such an investment is fully in line with its mission - to preserve and restore natural systems [8]. In the UK, the first organization to be engaged in impact investment was The Foundation for Social Entrepreneurs. The company issues targeted grants to social entrepreneurs [11]. All over the world, about 114 billion US dollars have been invested in social business today, compared to 77 billion US dollars in 2014. In the United States and Canada, the largest number of social investments is $40 \%, 14 \%$ in Europe, $10 \%$ in sub-Saharan Africa and $9 \%$ in Latin America. Eastern Europe and the countries of the former Union, in their turn, account for $6 \%$. Meanwhile, a half of the money from impact investors works in developed countries, the other half - in developing countries, but the share of the last year-on-year is growing.
Besides, $82 \%$ of the main offices of investment companies, which invest in social projects, are located in developed countries, from which almost $50 \%$ are in the USA and Canada, while one third is in Western Europe [10].

The most attractive direction of impact investing is the housing market $(22 \%), 16 \%$ are directed to cheap energy projects; microfinance to support small businesses is equal to $12 \%$. A sum of 8 billion US dollars, or $7 \%$ of the market volume, was invested in food production and agricultural development. $6 \%$ of funds of impact investors have been attracted to medical projects [10]. At the same time, there is a tendency to increase the share of investments in agriculture and medicine - a fourth of the investors surveyed said that they are going to expand the portfolio of projects in these areas in the near future.

Thus, impact investing is important for venture capital companies and investment banks, as well as for foundations and individuals. It provides benefits for all interested persons:

- to solve global problems. Impact investments can accelerate overcoming poverty, hunger and food security, increase access to quality education and medicine, achieve gender equality, ensure justice and promote peace. These significant problems in the world cannot be solved only through public funding. The achievement of the goals of sustainable development (SDG) in developing countries requires about 2,5 trillion US dollars. It is therefore private capital that is so necessary to finance sustainable development-related projects;

- achieve return on investment. Companies that finance projects aimed at solving problems of sustainable development will become financial winners in the future. The GIIN study shows that the overwhelming majority of the USD 15 billion in the United States market of impact investing is cost-effective [2];

- stabilize the investment portfolio. Impact investing can be a useful and beneficial addition to other investments in the investment portfolio. In Morgan Stanley's study, during which more than 10,000 Mutual investment funds were interviewed, it turned out that impact investing on average has lower volatility than corresponding funds without impact investments;

- investments in social, environmental projects and projects on quality health care provide an effective way to achieve individual or corporate social responsibility goals with significantly higher return on investment than donations or grants that simply distribute money;

- this type of investment allows an investor to declare its obligations as a responsible investor without refusing profits.

Foreign experience of impact investing shows wide possibilities of the use of this instrument in real investments. However, research has also shown some shortcomings in social investments. The main negative aspects of working in the social investment market remain the insufficient level of profitability and high financial risks when leaving projects.

For Ukraine, the practice of social investment, including impact investing, remains in its original state. The realization of social investment in Ukraine is largely focused on State and international support. Concessional lending projects for socially significant projects are being implemented in Ukraine through funds founded by foreign States and organizations. 
The state and dynamics of impact investment development processes and, accordingly, the conditions for their implementation can be seen in the participation of domestic enterprises, establishments and institutions in the UN Global Compact. This is the world's global voluntary, largest sustainable development initiative, which brings together business entities from 170 countries of the world into a single global forum for sustainable development through responsible and innovative governance. For today, 58 participants of the UN Global Compact have been registered from Ukraine. Among the top sectors in which they are registered are represented supporting service $(8$ participants), product production (3 participants), banks (2 participants), computer equipment and service (2 participants) and others. In particular, are registered such companies as ImpelGriffin, Vinnitsa Municipal Innovation Center, Aequo Law Firm, NGO Be-e-human Development Agency ICF Future, European Profiles SA of Ukraine, Osvitoria NPO, PLC AutoCat, Agricom Group, PLC "Metinvest Holding etc. [23].

\section{CONCLUSIONS}

Nowadays, there is an urgent need to transform the system of real investment and promote the development of social impact investments with the help of resources of international financial organizations, direct budgetary expenditures, private investments, charitable foundations etc. Despite the obvious advantages of socially responsible investing and its rapid development in the world, the establishment of impact investment on the Ukrainian market is hampered by the lack of awareness of Ukrainian entrepreneurs with the basic principles of impact investment production, little experience of social investment in the country, instability and unpredictability of the development of the Ukrainian economy etc.

The promotion of impact investing in Ukraine should cover the following areas:

- creation of a favorable information environment for impact investments and comprehensive introduction of a culture of social investment;

- development and implementation of preferential tools for activation of impact investing for business at the state level;

- integration of the impact investment development system into the government entrepreneurship support program;

- ensuring the interaction of existing business incubators in Ukraine with potential investors in the social sphere.

The development and an effective use of impact investment in the national economy can become an important factor in accelerating of economic and social growth.

\section{REFERENCES}

[1] Nicholls A., Paton R., and Emerson J. Social Finance. Oxford: Oxford University Press, 2015.

[2] Social Impact Investment. Organization for Economic Cooperation and Development (2018) Retrieved from URL: http://www.oecd.org/social/social-impact-investment.htm

[3] Decree of the President of Ukraine "The Strategy of Sustainable Development" Ukraine-2020 "dated January 12, 2015 No 5/2015 LIGA LAW. Retrieved from URL http://search.ligazakon.ua/ 1_doc2.nsf / link1 / U005_15.html
[4] Investment climate in Ukraine. Ministry of Economic Development and Trade of Ukraine. 2017 Retrieved from URL: www.me.gov.ua/Documents/Download?id=9d6a5f52-84bf-4713a02c. [in Ukrainian]

[5] Salamon L. M. The Revolution on the New Frontiers of Philanthropy: An Introduction. New Frontiers of Philanthropy. Oxford University Press, 2014. pp. 3-87

[6] Ivanova N.V. Social investment: an over view of foreign practices. Civil society in Russia and abroad. Higher School of Economics, 2013. - No. 3. - pp. 31-36. [in Russian].

[7] Hatfield Edwards. Social responsibility and the evolution of corporate philanthropy: An analysis of successful corporate-cause partnerships in an era of the global corporate citizen. (2015). Retrieved from URL: http://www.prismjournal.org/homepage.html

[8] What you need to know about impact investing. Global Impact Investing Network. (2017). Retrieved from URL: https://thegiin.org/impact-investing/

[9] Community Based Approach to Local Development. Project (2014). UNDP Urban Development Project Retrieved from URL: https: //cba.org.ua

[10] Olginskij K., Investments of influence in the world has become more. (2017). Portal "NewBusiness" 2007-2018, The Fund of Regional Social Programs "Our Future". Retrieved from URL: http://www.nbforum.ru/social/social_investing/investiciy-stalo-bolshe-2.html. [in Russian].

[11] Smal V., and Kokot V. What to know about social entrepreneurship. International Technical Assistance Project, Partnership for Urban Development, Federation of Canadian Municipalities, Kyiv, 2017. 58 p. [in Ukrainian].

[12] Resolution of the CMU "On the Establishment of the Ukrainian Social Investment Fund" No. 740 dated April 28, 2000 Retrieved from URL: http://zakon4.rada.gov.ua/ laws / show / 740-2000-\% D0\% BF. [in Ukrainian].

[13] Impact-investing: from $\$ 10$ billion to $\$ 228$ billion over three years. Journal "Business". (2018). Retrieved from URL: https://business.ua/spetsproekty/item/4009-impaktinvestuvannia. [in Ukrainian].

[14] Basiluk B.G. World experience of social investment and the possibilities of its adaptation in Ukraine. Social-labor relations: theory and practice, №2, pp. 370-377, 2017. Retrieved from URL: http://nbuv.gov.ua/UJRN/stvttp_2017_2_38. [in Ukrainian].

[15] Bugg-Levine A., and Emerson J. Impact Investing: Transforming How We Make Money While Making A Difference. - Jossey-Bass, 2011

[16] BlagovYu. E. Corporate Social Responsibility: The Evolution of the Concept. SPb.: "Higher School of Management", 2011. - 272 p. [in Russian].

[17] Kraplych R. Corporate Social Responsibility of Ukrainian Business: The Experience of the Ostrozky Foundation: A Guide for Business and Non profit Organizations. Order. R. Bovgir, S. Paysanidi, O. Kraplych, A. Kislov, and others. Rivne: Foundation for them. PrincesbenefactorsOstrozky, 2015. - 74 p. [in Ukrainian].

[18] Seryakov AV, and Shikhverdiyev A.P. Development of Corporate Social Responsibility in Ukraine. Global and national problems of economy, VN Mykolaiv National University. Sukhomlynsky, No. 9, pp. 136, 2018. [in Ukrainian].

[19] The Case Foundation Retrieved from URL: https://casefoundation.org

[20] What You Need to Know About Impact Investing. Global Impact Investing Network. (2016). Retrieved from URL https://thegiin.org/impact-investing/need-to-know/\#s1

[21] Eurosif (2016) European SRI Study 2016 Retrieved from URL http://www.eurosif.org/wp-content/uploads/2016/11/SRI-study-2016HR.pdf

[22] Eurosif (2018) European SRI STUDY 2018 Retrieved from URL http://www.eurosif.org/eurosif-2018-sri-study-launch-event/

[23] Official website of the United Nations Global Compact Retrieved from URL: https://www.unglobalcompact.org

[24] Morrison S. Bridges Ventures Overview (2014). Bridges Ventures. May, 2014 